\title{
METODE COOKING SEBAGAI UPAYA PENGENTASAN GIZI KURANG DAN GIZI LEBIH BALITA DI DESA CATUR, KINTAMANI, BANGLI, BALI
}

\author{
Ni Ketut Wiradnyani ${ }^{1}$, Ni Wayan Nursini ${ }^{2}$, Ni Putu Eny Sulistyadewi ${ }^{3}$, Purwaningtyas ${ }^{4}$, \\ I Gusti Ayu Wita Kusumawati ${ }^{5}$, Ida Bagus Agung Yogeswara ${ }^{6}$, I Gede Mustika ${ }^{7}$, \\ Dylla Hanggaeni Dyah Puspaningrum ${ }^{8}$ \\ 1,2,3,4,5,6,7,8 Universitas Dhyana Pura
}

wiradnyani@ undhirabali.ac.id, nursini@undhirabali.ac.id, enysulistyadewi@undhirabali.ac.id.purwaningtyas@undhirabali.ac.id,witakusumawati@undhirabali.ac.id,agungyogeswara @undhirabali.ac.id, igedemustika@undhirabali.ac.id, dyllahanggaeni@undhirabali.ac.id

\begin{abstract}
Abstrak
Tujuan pengabdian masyarakat oleh Program Studi Gizi Universitas Dhyana Pura menerapkan metode cooking adalah memberikan pengetahuan, keterampilan kepada Posyandu, ibu asuh yang mempunyai balita gizi kurang dan lebih. Solusi yang telah diberikan metode cooking by moist heat dan dry heat dalam mengolah berbagai bahan makanan dari nabati dan hewani membuat menu gizi kurang dan gizi lebih melalui metode ceramah, demonstrasi dan tanya jawab. Hasil postes menyatakan bahwa 88\% masyarakat posyandu dan ibu asuh gizi kurang dan lebih pada balita usia 2 -5 tahun mengetahui cara menggunakan metode cooking dalam membuat pizza teplon, roti dan pudding ubi ungu, soup pumkin, egg dishes, soto lobak, capcay, breaded lele satay, bread pumpkin, sari kacang hijau, dalam pemaparan ceramah maupun keterampilan dan target capaian solusi yang diharapkan mitra semakin bertambah dari hasil pre-test sebesar 11,5\%. Dari kegiatan ini pengetahuan dan kemampuan ibu asuh dan kelompok posyandu meningkat mengenai metode cooking yang dipergunakan dalam mengolah bahan makanan nabati dan hewani bagi pengentaskan masalah gizi kurang dan lebih meningkat sebesar $22 \%$. Kata Kunci : Gizi lebih, Gizi kurang, Moist heat, Dry heat, Desa Catur
\end{abstract}

\section{PENDAHULUAN}

Metode memasak sangat diperlukan untuk mempertahankan zat gizi yang terkandung dalam setiap bahan makanan yang diolah, cara memilih metode memasak (cooking) berdasarkan data hasil penelitian (Prasanna, K.D, Gunathilake, et al, 2018) bahwa menggoreng menyebabkan pengurangan bioaktif utama dan aktivitas antioksidan pada semua sayuran berdaun yang diuji. Namun, daun C. auriculata dan C. Asiatica yang dikukus dan direbus telah menunjukkan tingkat polifenol, flavonoid, dan kapasitas antioksidan yang lebih besar dibandingkan dengan daun segar.

Gizi buruk dan beberapa masalah kesehatan yang masih dirasakan oleh Masyarakat desa Catur sampai saat ini. Kondisi gizi yang buruk telah terjadi pada anak usia balita demikian juga masalah kurang gizi dan obesitas. Balita merupakan anak yang telah menginjak usia diats satu tahun hingga lima tahun atau usia anak di bawah lima tahun (Muaris, 2006). Berdasarkan berita Nusa Bali.com (2020) ditemukan dari data Balai Kesehatan Daerah dinyatakan bahwa ada 15 
orang balita. Data jumlah balita desa Catur banjar Mungsengan sendiri terdiri dari 37 balita dimana tercatat kondisi balita yang mengalami gizi kurang sebanyak 3 orang $(5,4 \%)$, banjar Lampu ada 31 dan $2(6,5 \%)$ orang anak diantaranya yang mengalami gizi lebih dan gizi buruk. Kejadian gizi buruk salah seorang balita disebabkan oleh factor bawaan sejak dalam kandungan dan kondisi yang dilahirkan premature yang disertai dengan kebutaan, selebihnya balita dengan rata-rata usia 3-4 tahun mengalami gizi kurang dengan keadaan stunting. Keadaan balita kurang gizi karena pola makan masyarakat dalam hal ini pengetahuan tentang mengolah makanan bergizi, pola makan, pemberian asupan yang benar untuk balita yang belum maksimal. Riskesdas tahun 2013 dalam profil kesehatan Provinsi Bali (2014), diketahui bahwa prevalensi balita yang mengalami gizi kurang sebesar 10,2\%, sedangkan yang mengalami gizi lebih mencapai 5,5\% (Dinas Kesehatan Provinsi Bali, 2015).

Upaya prodi gizi Universitas Dhyana Pura menghadapi masalah ini adalah memberikan pengetahuan, penyuluhan pendampingan skill dalam hal pembuatan asupan dengan berbagai metode cooking untuk mendapatkan menu gizi seimbang dalam mengatasi terjadinya masalah gizi. Beberapa masalah yang menjadi skala prioritas untuk diberikan solusi: 1) kurangnya maksimalnya pengetahuan para ibu asuh balita mengenai metode cooking by moist heat untuk membuat menu yang bergizi, 2) keterbatasan ketersediaan alat dalam menggunakan metode cooking untuk pengolahan makanan menjadi menu yang dapat memperbaiki status gizi anak balita, 3) kurangnya kemampuan menerapkan cooking by dry heat dalam mengolah makanan menjadi menu yang menarik berbasiskan pangan lokal yang sudah ada dan melimpah dengan menu yang sederhana dalam waktu yang sangat singkat untuk pemenuhan gizi seimbang anak asuh balita

\section{METODE}

\section{A. Objek Pengabdian Kepada Masyarakat}

Objek Pengabdian Kepada Masyarakat ini

adalah masyarakat dari kader posyandu dan masyarakat yang terkena dampak langsung yaitu masyarakat balita dengan gejala gizi kurang dan masyarakat balita yang mengalami gizi lebih Desa Catur Bangli. Pengabdian masyarakat ini dilakukan hingga bulan Desember selama tiga bulan pada tahun 2020.

\section{B. Survey Pendahuluan}

Survey pendahuluan dilakukan secara daring kepada beberapa, Balai Kesehatan Daerah (BKD), Puskesmas Provinsi, tokoh masyarakat seperti perbekel Desa Catur Bangli sebagai informan utama, karena dalam situasi covid-19, untuk mengumpulkan data dan terkait akan persiapan yang dilaksanakan pada program pengabdian Prodi Gizi, Fakultas Kesehatan Sains dan Teknologi Universitas Dhyana Pura.

\section{Sosialisasi}

Sosialisasi terlebih dahulu kepada tokoh Desa Catur dengan secara langsung kepada kader posyandu melalui ceramah dan pendampingan dengan protokol kesehatan ketempat terjadinya kasus yang sudah ditentukan, dengan memberikan penyuluhan, motivasi kepada orangtua asuh melalui posyandu dalam : pengenalan metode cooking by moist heat, cooking by dry heat dan utensil untuk pembuatan menu olahan sederhana seperti: pizza teplon, roti dan pudding ubi ungu, soup pumkin, egg dishes, soto lobak, capcay, breaded lele satay, bread pumpkin, sari kacang hijau yang bergizi tinggi, serta memberikan menu yang sudah dibuat kepada anak balita bermasalah gizi.Menjelaskan langkah-langkah sistematis yang dilakukan dalam kegiatan pengabdian masyarakat.

\section{Pelatihan}

Metode Pelatihan yang digunakan adalah memberikan keterampilan pemberdayaan menu kepada ibu sebagai upaya pengentasan gizi kurang dan gizi lebih balita, kader posyandu maupun BKD, peserta dari orang tua yang anaknya mengalami kasus dan kader posyandu dibatasi hanya 10 peserta yang diberikan pelatihan metode cooking dalam pembuatan menu-menu seperti: pizza teplon, roti dan pudding ubi ungu, soup pumkin, egg dishes, soto lobak, capcay, breaded lele satay, bread pumpkin, sari kacang hijau yang dapat 
meningkatkan maupun menurunkan berat badan yang memperdayakan sumber daya alam melimpah hasil pertanian potensi Desa setempat diselenggarakan di Balai Desa Banjar Catur, Desa Catur, Kintamani, Bangli

\section{HASIL DAN PEMBAHASAN}

\section{Hasil Pengabdian}

Sebagian besar masyarakat Desa Catur memiliki mata pencaharian bertani dan berladang, dan beberapa dari mereka sebagai buruh tani, petani penggarap pada tuan tanah, diantaranya menggarap lahan perkebunan kopi dan ladang hortikultura yang terdiri dari buah jeruk kintamani, cabe, sayuran yang hidup di daerah dingin seperti Desa Catur ini. Masyarakat petani bekerja selama kurang lebih 8 sampai 9 jam pada lahan pertanian sebagai buruh yang mendapat upah harian. Pekerjaan rutin yang dilakukan oleh masyarakat buruh tani ini sangat menyita waktu mereka untuk memelihara ataupun mengurus anak-anak mereka terutama para buruh tani wanita yang masih memiliki anak-anak balita dengan rentang usia 1 sampai 5 tahun (Berita Desa, 2019).

Anak-anak mereka diasuh dengan cara menitipkan pada saudara, tetangga dengan mendapatkan pemeliharaan dengan asupan gizi seadanya. Buruh tani yang bekerja mulai jam 8 pagi, merasa kehabisan waktu untuk memikirkan ataupun menyediakan makanan yang bergizi terutama bagi balita mereka. Anak balita seharusnya mendapatkan perhatian khusus dalam hal kepentingan pertumbuhan dan perkembangan tubuh mereka untuk mendapatkan kualitas pertumbuhan secara fisik, kemampuan berfikir dan kelangsungan pertumbuhan dan perkembangan tubuh mereka, status gizi (Dini, N.I., Siti F.P., dan Suyatno, 2017). anak-anak balita mereka sangat ditentukan oleh makanan yang dikonsumsi (Andriani, M. \& Wirjatmadi, B, 2012). Alasan yang sangat mendasar ketika mendapatkan data dari Puskesmas Provinsi Bali bahwa masih ada masalah gizi kurang dan gizi lebih pada balita di Desa Catur. Melalui pembicaraan dengan beberapa orang tua anak balita secara langsung dapat diketahui bahwa persoalan yang terjadi diantaranya anak balita yang gizi kurang dan gizi lebih, karena hampir sebagian besar para ibu asuh anak memiliki jawaban: tidak bisa menggunakan metode memasak dengan proses yang panjang, kurang menguasai teknik memasak praktis, malas untuk mengolah makanan, dan mereka hanya memberikan makanan jajanan seperti sejenis ciki (Eny, S, dkk, 2020), dan jajanan kemas lainnya yang dilakukan hampir setiap hari, tanpa memperhatikan asupan yang bergizi, sehingga beberapa diantaranya anak balita mengalami kebutaan disamping karena lahir secara premature (Anggiruling, D.O., Ikeu E., dan Ali K, 2019). Keadaan buruh tani yang mendasar adalah tingkat pendidikan ibu asuh yang rata-rata berada di tingkat $\mathrm{SD}$, dan sekolah menengah atas, disamping status pekerjaan dan tingkat ekonomi keluarga dimana hasil buruh tani setiap hari rata-rata dari 60.000 sampai 100.000 jika bekerja, dengan beban konsumsi tiga sampai lima orang setiap hari (Berita Desa, 2019)

Jika dilihat dari hasil utama pertanian desa Catur itu sangat melimpah dengan sayur mayur dan buah-buahan yang segar, seperti sawi putih, brokoli, lobak, Jepang, strwbery, nangka, papaya, pisang, kentang, wortel, labu kuning, ubi jalar. Semua itu mampu dibeli oleh petani karena harganya sangat murah, mudah diperoleh, kendatipun demikian para ibu asuh masih belum memahami arti asupan gizi dari hasil ladang yang melimpah tersebut, dan bagaimana cara mengolah dengan benar, dan tidak menyita waktu bekerja, mengingat aktivitas fisik mereka sangat melelahkan untuk membuat makanan yang bergizi sebagai masalah yang sangat mengganggu aktivitas sebagai buruh tani (Wiradnyani, 2020)

Desa Catur telah mendapat bantuan dari pemerintah seperti ikan patin, lele yang sudah memberikan panen melimpah serta harga yang murah dan dapat digunakan untuk memperbaiki asupan gizi anak balita, namun mereka belum mampu membuat menu yang memiliki sentuhan teknologi pengganti snack yang mereka beri kepada anak balita untuk memenuhi asupan gizi sehari-hari. Belum memahami dari sumber makanan nabati tersebut dapat memberikan sumber protein hewani untuk memenuhi kebutuhan gizi seimbang anak balita ( Wiradnyani, 2020)

Berdasarkan pengamataan dan survey 
masyarakat Desa Catur, maka ditemukan beberapa permasalahan yang menjadi prioritas untuk dicarikan solusi melalui pengabdian masyarakat yaitu: 1) kurangnya maksimalnya pengetahuan para ibu asuh balita mengenai metode cooking by moist heat untuk membuat menu yang bergizi, 2) keterbatasan ketersediaan alat dalam menggunakan metode cooking untuk pengolahan makanan menjadi menu yang dapat memperbaiki status gizi anak balita, 3) kurangnya kemampuan menerapkan cooking by dry heat dalam mengolah makanan menjadi menu yang menarik berbasiskan pangan lokal yang sudah ada dan melimpah dengan menu yang sederhana dalam waktu yang sangat singkat untuk pemenuhan gizi seimbang anak asuh balita

\section{Pembahasan}

Solusi kurangnya maksimalnya pengetahuan para ibu asuh balita mengenai metode cooking by moist heat untuk membuat menu yang bergizi adalah dengan cara memberikan ceramah dilanjutkan dengan melatih posyandu dan ibu asuh balita desa Catur mengenai bagian dari cooking by moist heat. Salah satu metode yang dipergunakan adalah boiling yaitu memasak dengan menerapkan panas menggunakan perantara zat cair yaitu air atau minyak atau berbagai sauce, syrup dan sejenisnya.

Tim PKM dari prodi Gizi memberi ceramah, melatih, mendampingi cara membuat sotola yaitu soto yang menggunakan bahan sayuran dari lobak sebagai sumber serat dan ayam sebagai sumber protein hewani. Sebagai metode awal yang paling penting dilakukan pada metode ini adalah adanya perlakuan blanching sebelum perlakuan boiling yang bertujuan untuk membuang kotoran, lemak yang ada pada daging/tulang dan menutup pori-pori daging agar juice yang mengandung gizi tidak larut pada air lebih awal dan terbuang lewat penguapan. Setelah blanching daging atau bahan nabati tertentu harus direndam segera pada air es atau air dingin untuk tujuan menghindari terjadinya penguapan berlanjut sehingga senyawa nutrisi bahan tetap tersimpan dalam jaringan bahan hewani atau nabati. Setelah perlakuan blanching selesai kemudian daging,tulang, sayuran di boiling selama satu jam ditambah bumbu untuk memutuskan connective tissue yaitu jaringan yang terdapat pada bahan hewani untuk memudahkan keluarnya zat gizi dari bahan tersebut, sedangkan dari tanaman adalah jaringan vacuala sel. Kemudian sotola di boiling dengan api kecil selama satu jam,saat ini terjadi keluarnya zat gizi dari jaringan bahan sehingga soto lobak penuh dengan gizi yang bermanfaat untuk gizi kurang anak balita Desa Catur. Sotola diberikan sebagai makanan utama yang ditemani dengan nasi putih.

Metode yang kedua yaitu braising pada pembuatan sari kacang hijau, yaitu dengan merendam biji kacang hijau selama 3 jam, dilanjutkan dengan boiling 15 menit kemudian ditutup rapat sampai dingin, metode ini sangat menghemat gas atau listrik, ketika dilanjutkan dengan memblender sampai lembut, dan dikemas sebelum dipanaskan 5 menit saja, hemat waktu boiling 50\% dibandingkan memasak sari kacang hijau pada metode lazimnya, hal ini disamping hemat bahan bakar gizi dari sari kacang hijau terutama vitamin B12, karbohidrat akan lebih tinggi dari sebelumnya (Winarno, 2019).

Soup pumkim merupakan makanan dalam bentuk cair yang dimakan setelah makanan pembuka yang bertujuan untuk memberikan waktu toleransi kepada pencernaan untuk menu yang lebih ringan dan lembut, sehingga pencernaan tidak mudah kaget dalam mencerna makanan yang diberikan secara bertahap dalam sifat atau jenis menu yang dihidangkan. Soup pumkim sangat cocok diberikan pada anak balita yang mengalami masalah gizi karena lebih mudah diserat dan kandungan karbohidratnya sangat cepat diserap usus disamping itu lebih cepat meningkatkan berat badan balita.

Pisang topping dimasak dengan cara stewing yaitu memasak dengan menggunakan cairan jumlahnya lebih sedikit dari bahan padatan dengan penerapan panas api langsung yang sangat kecil dengan tujuan untuk mendapatkan souce yang kental (dimiglace yaitu setengah kental) diikuti dengan cara pembuatan topping dari bahan yang sangat sederhana dan mudah dibeli yaitu susu bubuk dancow dan sponge 28 sertta gula halus yang dibelnder menghasilkan whipping cream yang harganya sangat mahal menjadi sangat murah ketika di aplikasikan ke menu soup pumkim dan pisang topping. 
Menu- menu yang menggunakan metode cooking by moist heat seperti tertera pada Gambar 1 .

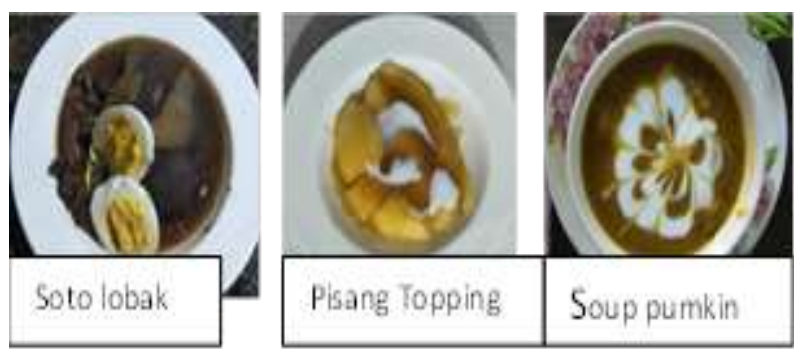

Gambar. 1. Penerpan Cooking By moist heat pada menu soto lobak, Pisang topping, soup pumkin

Solusi mengatasi keterbatasan ketersediaan alat dalam menggunakan metode cooking untuk pengolahan makanan menjadi menu yang dapat memperbaiki status gizi anak balita, dengan cara melakukan kombinasi cooking by moist heat dengan cooking by dry heat. Mixed apppetit menggunakan bahan roti tawar dibuat dengan cara di steam terlebihdahulu klemudian untuk mendapatkan warna coklat dengan cara melakukan roasting sistem bakar dengan teplon menggunakan double base utensil, api yng sangat kecil. Morney broccoli dilakukan dengan cara merebus broccoli dengan metode boiling kemudian untuk mendapatkan warna diatasnya tidak menggunakan Salamander yang harga equipment ini sangat mahal tetapi menggunakan penutup panci yang sudah tidak dipakai untuk diletakan bara dari arang bakar diatasnya, kedua menu ini sangat praktis bisa dalam pengolahanya tidak membutuhkan waktu banyak dan dalam prosesnya bisa dilakukan sambil mengerjakan pekerjaan yang lain. Makanan ini menjadi makanan pembuka yang sangat bergizi, memiliki serat dan karbohidrat yang cukup untuk angka kebutuhan gizi anak balita. Brokoli dengan sauce terdiri dari susu dan tepung terigu dan keju sebagai topping brokoli sangat menunjang gizi balita desa Catur karena kaya akan protein, serat, dan zat gizi makro.
Penampilan mixed appetite dan Morney Broccoli seperti disajikan pada Gambar 2.
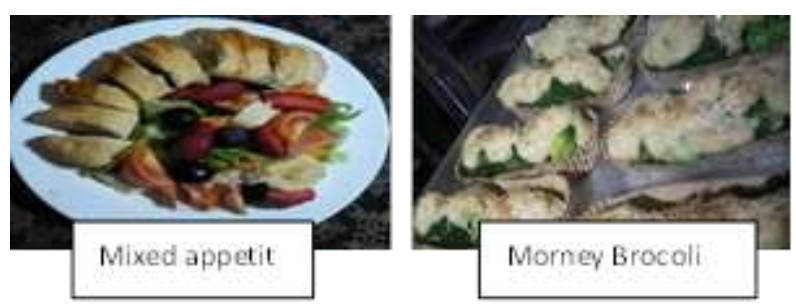

Gambar 2. Penerapan Cooking by combination method pada menu mixed appetit, Morney Brocoli

Solusi mengatasi kurangnya kemampuan menerapkan cooking by dry heat dalam mengolah makanan menjadi menu yang menarik berbasiskan pangan lokal yang sudah ada dan melimpah dengan menu yang sederhana dalam waktu yang sangat singkat untuk pemenuhan gizi seimbang anak asuh balita, adalah dengan cara memperdyakan teplon, panci atau work yang dimiliki penduduk setempat untuk disituasikan menjadi seperti oven yaitu melapisi tungku kompor dengan teplon yang sudah tidak dipakai atau sarangan pengukus sebagai double bottom untuk mendapatkan serapan panas tidak dengan sentuhan api secara langsung, dengan api yang sangat kecil dan ditutup maka menu pada Gambar 3. Tidak membutuhkan alat baru seperti Oven yang harganya sangat mahal, tetapi penduduk Catur memiliki skill teknik dalam memperdayakan alat dengan menghasilkan menu yang istimewa seperti roti ketela ungu, roti labu kuning, pizza teplon yang sangat bergizi.

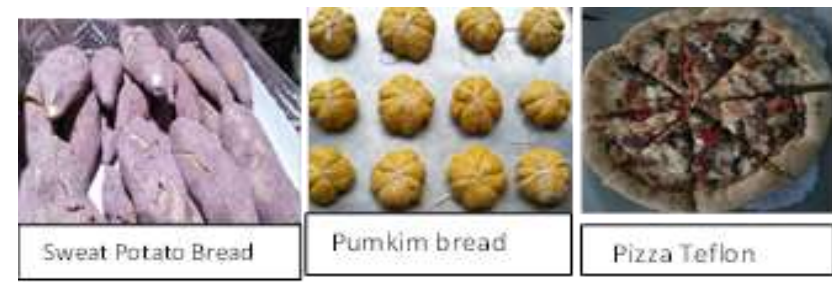

Gambar 3. Penerapan Cooking by dry heat pada menu sweat potatoes bread, pumkin bread, pizza Teplon 
Hasil yang diperoleh pada PKM metode memasak untuk pengentasan gizi rendah dan lebih di Desa Catur Kintamani, Bangli berdasarkan hasil post-test adalah terjadinya peningkatan pengetahuan, ketrampilan dan motivasi pada penerapan metode cooking by moist heat, cooking by dry heat, atau kombinasi keduanya dari 30 peserta menunjukkan bahwa mereka mengerti dan sering mengaplikasikan di rumah menggunakan metode-metode : blanching (96\%), boiling (80\%) , braising (93\%), stewing (87\%), shallow frying (83\%), Oven (90\%), jika dibandingan dengan prosentase saat pre-test, keadaan ini seperti terlihat pada Gambar 4.

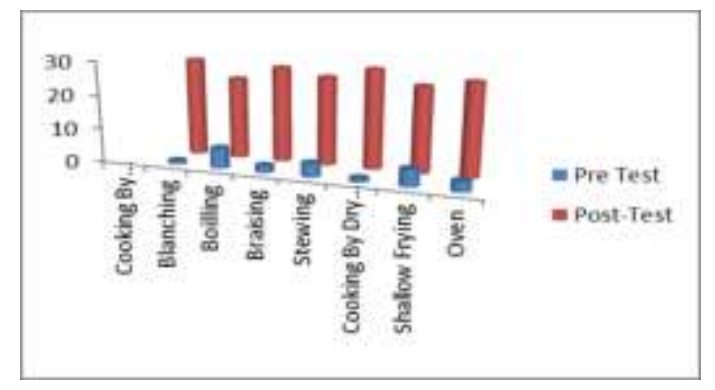

Gambar 4. Grafik Prosentase metode Cooking yang telah diterapkan oleh Ibu Asuh dan Posyandu Catur Bangli Bali

\section{KESIMPULAN}

Pelaksanaan pengabdian masyarakat diadakan selama 4 hari untuk memberikan solusi tentang pembuatan menu gizi kurang dan gizi lebih, berupa ceramah, demonstrasi dan tanya jawab. Hasil pengabdian pembuatan menu seperti pizza teplon, roti dan pudding ubi ungu, soup pumkin, egg dishes, soto lobak, capcay, breaded lele satay, bread pumpkin, sari kacang hijau,dalam pemaparan ceramah, kertrampilan dan target capaian solusi yang diharapkan mitra semakin bertambah dengan hasil pre-test sebesar $11,5 \%$. Rata-rata hasil posttest yaitu $88 \%$ dari seluruh ibu asuh dan kelompok posyandu mengetahui tentang menggunakan metode cooking untuk mengentaskan masalah gizi pada anak usia 2-5 tahun. Dari kegiatan ini pengetahuan dan kemampuan ibu asuh dan kelompok posyandu mengenai metode cooking by moisth heat, cooking by dry heat maupun kombinasi keduanya bahan pangan dan kandungan serta kegunaanya bagi pengentaskan masalah gizi meningkat sebesar $22 \%$.

\section{UCAPAN TERIMAKASIH (Bila ada)}

Pengabdian Masyarakat ini dapat terlaksana dengan baik berkat bantuan hibah PT Universitas Dhyana Pura melalui LPPM dengan skema Penghabdian Program Study. Terimakasih kepada perbekel dan masyarakat Desa Catur yang terlibat dalam pelaksanaan pengabdian masyarakat ini dapat berjalan dengan baik.

\section{REFERENSI}

Prasanna, K.D, Gunathilake, et al, 2018. Effect of Different Cooking Methods on Polyphenols, Carotenoids and Antioxidant Activities of Selected Edible Leaves: mdpi.

Muaris, H. 2006. Sarapan Sehat Untuk Anak Balita. Jakarta : PT. Gramedia Pustaka Utama.

Nusa Bali.com, 2020. Kasus Stunting Di Bangli Tinggi,ttps://www.nusabali.com/berita/8546 0/kasus- stunting-di-bangli-tinggi.

Dinas Kesehatan Provinsi Bali. 2015. Bali. Profil Kesehatan Provinsi Bali 2014.

Berita Desa, 2019, Desa Catur Rintis Pengembangan Pasar Agro Hortikultura, Media Komunikasi dan Trasparansi Pemerintah Desa Catur untuk Seluruh Masyarakat, https://catur.sid.my.id/artikel/2019/7/8/desacatur-rintis-pengembangan-pasar-agro$\underline{\text { hultikultura }}$

Dini, N.I., Siti F.P., dan Suyatno. (2017). Hubungan Konsumsi Makanan Jajanan Terhadap Status Gizi 
(Kadar Lemak Tubuh dan IMT/U) Pada Siswa Sekolah Dasar (Studi di Sekolah Dasar Negeri 01

Andriani, M. \& Wirjatmadi, B. (2012). Peranan Gizi dalam Siklus Kehidupan. Jakarta : Kencana Prenada Media Group.

Eny Sulistyadewi, dkk, 2020. Worshop Ekslusif dan MPASI bagi Ibu di Desa Catur, Kintamani, Bangli, SINAPTEK, Universitas Dhyana Pura Bali, Proceeding: vol (2) 151$154 \mathrm{~h}$

Anggiruling, D.O., Ikeu E., dan Ali K. (2019). Analisis Faktor Pemilihan Jajanan, Kontribusi Gizi dan Status Gizi Siswa Sekolah Dasar. Jurnal MKMI, 15(1), 81-90.

Wiradnyani,N.K, et al, 2020, Compounds and Antioxidan Components of Various PostRushing Loloh With Various Utensil Ingredients, Product Loloh Of Ukm Pejeng Kelod Village, Tampak Siring Gianyar, Bali, Pro Food (Jurnal Ilmu dan Teknologi Pangan), Vol 6 (2) 6424-6441

Winarno, F.K., 2019. Farmasi Kimia Pangan Dan

Gizi. F.K Winarno. Gramedia 